DOI: 10.47750/jett.2021.12.01.020

\title{
The phenomenon of a future teacher's scientific-research culture under the new socio-cultural conditions
}

Viktoriya Tusheva ${ }^{1}$

\author{
Journal for Educators, Teachers and Trainers, Vol. 12 (1) \\ https://jett.labosfor.com/
}

Date of reception: 10 October 2020

Date of revision: 09 January 2021

Date of acceptance: 08 April 2021

Viktoriya Tusheva (2021). The substantiation of the essence of a future teacher's professional culture as a personal phenomenon from the standpoint of the culturological approach. Journal for Educators, Teachers and Trainers, Vol. 12(1). 154 - 160.

${ }^{1}$ Professor, Doctor of Pedagogical Sciences, H.S. Skovoroda Kharkiv National Pedagogical University, Kharkiv, Ukraine 

as a personal phenomenon from the standpoint of the culturological approach

Viktoriya Tusheva ${ }^{1}$

${ }^{1}$ Professor, Doctor of Pedagogical Sciences, H.S. Skovoroda Kharkiv National Pedagogical University, Kharkiv, Ukraine

\begin{abstract}
The article covers various definitions of the concept of "culture", which expand and fill the concept of "a teacher's professional culture" with a new meaning and content. The specified personal phenomenon is viewed on the basis of the culturological approach and it manifests itself in the permanent process of professional and personal development and self-development, identifying humanistic orientation, self-actualization, and, in this regard, the ability to carry out purposeful activities, find the new meanings of the professional life, professional "self", professional functions, find the ways of one's "essential forces" realization. The definition of the problem field allowed us to identify the tasks of the possible directions of the formative process in relation to a future teacher's professional culture. The task should be focused around future teachers' culturological and worldview preparation.
\end{abstract}

Keywords: culturological approach, cultural values, future teacher's professional culture, professional self-determination, professional self-realization, self-development, personality culture, culturological preparation, worldview preparation.

\title{
PROBLEM TOPICALITY
}

The quality of a society's socio-cultural development largely depends on the professional and personal characteristics of teachers, a future teacher's ability for quick adaptation and personal realization under the new conditions of professional life, purposeful professional and acmeological self-development and selfdetermination, the ability to produce new ideas, which is achieved owing to the holistic development of the social and professional intelligence. In this context, the idea from professionalism to understanding the system of culture, and from understanding the holistic culture to understanding the meaning and content of the profession becomes especially important.

For Ukrainian education the introduction of the purposes of the UNESCO World Commission on Culture and Development is of the urgent methodological need. These purposes provide for the widest possible use of the cultural potential at both individual and national levels, since in the long run, it will support the humanistic and humanitarian development of the society, the state and idividuals.

The Pedagogical Constitution of Europe, which defines a single value and methodological platform for a new teacher's preparation for the united Europe of the XXI century, emphasizes that teacher training in accordance with the unified scale of general human values and considering national characteristics is the main framework around which the processes of pedagogical education modernization and innovation in the modern European space should be carried out. A European teacher is meant to find answers to the challenges of the era and promote pupils' and students' audience introduction to the bosom of progress of scientific knowledge, high culture, socio-practical experience of generations, universal socio-cultural values, the spirit of humanism and humanity.

Thus, the purpose of the article is to highlight the essence of a futures teacher's professional culture, its professional and personal markers, its value orientations, taking into account the modern socio-cultural trends in pedagogical education on the basis of the culturological approach; to determine the possible directions of the process of formation of a specialist's professional culture as a personal phenomenon.

There are a lot of works in the scientific and pedagogical literature

(V.L. Benin, Ye.V. Bondarevska, V.M. Hrynova, I.A. Ziaziun, I.F. Isaiev, A.V. Mudryk, V.V. Radul, V.A. Slastonin and others) which study the features of formation of professional and pedagogical culture as a didactic phenomenon. However, the theoretical realization of a future teacher's professional culture from the standpoint of the culturological approach requires further scientific reflection. 


\section{MAIN RESEARCH MATERIAL PRESENTATION}

Basing on the fact that the leading system-forming factor of a teacher's formation and professional-personal self-reproduction is the formed professional culture, which creates a foundation for the development of all its other types and determines the vector of methodical and didactic direction of professional training of future specialists in pedagogical education, we think it essential to turn to the concepts "culture" and a "teacher's professional culture" and highlight its essential characteristics on a culturological basis.

Our analysis of existing conceptions and theoretical deduction of the concept of "culture" allows us to focus on definitions that expand the understanding of the essence of culture, fill the content "a teacher's professional culture" with the new meaning and contents. Thus, we consider culture as:

- a qualitative certainty of the phenomenon, which does not only allow us to identify and distinguish it from others, but also to point at the degree of formation, development and relative perfection;

- value significance and "completeness" of any phenomenon, which allows us to consider it in terms of inclusion in the set of achievements in the fields of science, education, lifestyle; in this sense, culture itself becomes a social meta-value, combining values in their cultural-historical and national-cultural contexts;

- the process and mechanism of preservation and transition of values, their constant generation and transformation in the field of education, communication and creativity;

- the environment of socially significant development of humanity and the space of free emergence of new elements of creative experience, its self-organization, self-development and self-renewal.

Despite the expansion of the field of culturological research, the differences in conceptual, theoretical and methodological provisions on the phenomenon of culture, the scientists come to a general conclusion: in its essence, culture as a personal phenomenon is an individual's time-developed self-realization. This idea can be proved by the works by A.I. Arnoldov, V. S. Bibler, M. K. Mamardashvili, V. M. Mezhuiev, M. S. Rozov, Yu. M. Lotman and others.

From the point of view of B.S. Hershunskyi [4], culture is the highest manifestation of human education and professional competence. It is at the level of culture, as the scientist emphasizes, that human individuality can be expressed in the fullest possible way. Culture can be represented as a system of knowledge and ideas of people, the sphere of educational and developing activity in the broadest sense of the word, the means of realization of the function of learning.

Thus, the application of culturological approach in the modern pedagogy focuses on a broad approach to culture and education in the context of their general philosophical understanding, and the process of personality formation in the educational space from the standpoint of this approach requires changing the nature of the pedagogical process towards the emphasis of personal direction.

We place a special importance in the coordinate system that comprise the content of a teacher's professional culture, to the development of a teacher's personal culture, without which a teacher can't work in the ideology of cooperation with a child and to be the facilitator of his interests. In this sense, a personal culture is manifested in the individual's universality and diversity, his spirituality and intellectuality. By developing spiritually, a teacher humanizes the whole sphere of his relationships with reality, spiritualizes it, perceiving any object of reality as part of his internal world, and evaluates the reality through the prism of spiritual values. Consequently, a teacher's spirituality gives a new, high quality to professionalism, becomes its standard.

It is important for us to understand the personality culture as a combination and an ensemble of socio-cultural qualities that manifest themselves in life not in quantitative and formal, but in complex, qualitative parameters that determine the productivity of the activity and provide for its value character. A personality culture represents a meaningful content of a person's life activities, style, lifestyle and the scale of his harmonious, diverse development; a cumulative creation which determines the quality of specific forms and kinds of a person's behaviour, the level, completeness and integrity of a person's development.

In the logic of the culturological approach, an individual's culture presupposes the development and harmony of all its components, their integral formation in the activity. Meanwhile, various aspects of a person's essence as the subject of culture (consciousness, self-consciousness, spirituality, morality, creativity) are percieved in a non-hierarchical connection as the sides of a person's culture. A culturological approach allows us to interpret the assimilation of culture as a process of personal discovery, the creation of the world of culture inside oneself, taking part in the dialogue of cultures, in which individual and personal actualization of the senses within it take place. The culture serves as a criterion for the degree of development of humanity inside a person himself, expressing his position in the system of norms and spiritual and moral values.

It is in the sense-bearing field of culturological paradigm that the uniqueness of a person is emphasized, the role of the human factor is strengthened, especially such personal qualities as his identity and self-worth, and a person's intellect and creative potential are viewed as the main productive forces of society and education. According to the shrewd statement of M.S.Kahan, "a person becomes a direct culture-genic subject, that embodies himself in culture, makes it his other self and is formed by it" [11, c. 47]. Thus, culture serves as an internal impulse of personal development and a "mechanism", which provides it.

In the context of the chosen problem the scientists' point of view

(V.A. Provotorov, V.A. Slastonin) 
attracts our attention. According to this point of view, a specialist's professional culture is related to the process of holistic personal culture development, which is reflected in the development of worldview and methodological thinking that are interrelated and are based on "cultural" knowledge. It is such knowledge, according to scientists, which serves as the basis for professional culture. Thus, the analysis of the given definition makes it possible to pick out such key features as worldview, thinking and knowledge, which are correlated with personal and professional characteristics of a person's culture.

Cultural values become the main condition, a means of formation of a teacher's personality, his worldview, behavior and, in a broader sense, the meaning of life. As A.I. Arnoldov [7] points out, no matter from what perspective we turn to culture, whether it is axiological, ethical, aesthetic or socio-psychological, the interdependence of the processes of a person's improvement as the carrier of worldview and as a creator of cultural values will always be traced and stimulated. This point leads us to the conclusion that the formation of a teacher's worldview is determined by cultural values, on the one hand, and, on the other hand, - worldview development contributes to a specialists' spiritual improvement and self-development and is reflected in personality culture formation. The higher the level of values in a culture, the more the culture requires awareness of these values from its representatives. The higher the wholeness of the system of values in a given culture is, the higher the integrity of spiritual life in this culture. The higher the level of a person's culture is, the more productively he acts as a creator, carrier and consumer of values, and, consequently, the richer and more perfect the culture as a personal feature, which becomes the source of a person's development.

H.A. Ball [2] offers a reasonable vision of a specialist's professional culture by picking out the prerequisites for its formation, focuses on mastering the strategies of creative activity and personal knowledge not only recorded in manuals and reference books, but also informal knowledge, transferred while communicating with professionals, developed with the professional intuition. Thus, the scientist focuses on the creative dominance of a speciaslists's personality, the development of his intellectual sphere.

So, we can generally characterize a future teacher with a developed professional culture: he is an intellectually erudite and morally responsible personality, possessing productive ways of solving professional and pedagogical tasks. He possesses individually developed strategies of professional activity, realizes and comprehends himself as a subject of the pedagogical process, shows humanistic orientation, implements higher human ideals and axiological models of educational systems into the pedagogical practice, has an idea about the professional ideal and the ways to achieve it, realizes the search for personal senses, purposes and values in the professional life, basing on personal "meaning-creating fund" and the experience of multidimensional perception of pedagogical reality.

In order to reveal the mechanism of functioning of a teacher's professional culture, we turn to the general, special and single subordinate series of concepts, developed by V. A. Slastonin [10] in the system of general human categories. The concepts are: general culture $\rightarrow$ professional culture $\rightarrow$ pedagogical culture $\rightarrow$ professional-pedagogical culture.

This point of view allows us to speak about the professional-pedagogical culture of the teacher as the one that is based on his individual and personal culture and is a part of general human culture, which integrates historical and pedagogical experience and regulates the whole sphere of pedagogical interaction. The ideas about a teacher's culture as the basis for his professional-pedagogical culture emphasize its uniqueness and nonreplacability.

In this aspect, a teacher's professional culture synthesizes all the required components of general culture, actualizing and manifesting itself in accordance with his professional strategy and needs for creative and professional self-realization. Professional culture as an integral indicator of creative beginning of a teacher's behavior and activity consists in the unity and interaction of all the components. In particular, a person's thesaurus and outlook characterize his searching and cognitive contents, intellectual potential, the range of interests provides for cultural and pedagogical orientation of a specialist's personality; knowledge, skills and abilities set the breadth of a person's subject-practical pedagogical and theoretical experience; methods of activity and being aware of them regulate a person's deeds and actions. Thus, a developed teacher's professional culture is the only process of knowledge and experience accumulation and their qualitative implementation in activities and behavior. It is formed according to the norms of conformity of methods of professional and creative realization to the functional status of a teacher. The culture becomes a state, a result and a productive process of accumulation and creation of social-humanistic, pedagogical values; provides the development and harmony of all the components, and their integral formation in activity. The essence of such a culture is manifested in the holistic harmony of a teacher.

Considering the professional culture of a teacher as the one that involves the implementation of axiological, spiritually filled models of educational and pedagogical systems, the implementation of ideas of personalityoriented approach, the principles of humanistic educational paradigm in pedagogical activities, aimed at students' self-actualization, turning to all the richness of human culture in applying pedagogical technologies, we emphasize the need to find one's own conception in viewing the pedagogical process, the rejection of unambiguous models of educational reality, creation and transmission general universal human ideals 
throughout one's life. The main ideals are humanity, moral responsibility, openness to interaction and partnership. As V.P. Andrushchenko points out [1], spirituality organically combines rational and sensory components of human thinking. It is the harmonious unity of truth, kindness and beauty. Feelings and mind do not contradict, but complement each other, interact, embrace the contradictory world in its integrity. The abovementioned interaction is carried out in the activities and communication of people in a society. Without activity, spirituality loses its historical rational-sensory outlines or social sense.

Scientists (O.A. Dubaseniuk, L.M. Mitina, M.S. Priazhnikov, V.A. Slastonin, S.A. Smyrnov, and others) emphasize that the achievement of higher professional levels is naturally accompanied by a teacher's personal reproduction. This position is confirmed by the statements of L.M.Mitina [6] on the inseparability of professional development from the personal one as the principle of self-development, which determines a person's ability to transform one's life activity into the subject of practical transformation. Therefore, real professional development is, first of all, a self-development as a teacher's internal activity connected with the qualitative transformation of himself, his inner world, a continuous process of a personality self-design.

We can distinguish a double pedagogical result of self-development: on the one hand - these are switching (variable) processes that are modelled and occur in the personal-individual and professional-acmeological direction, and, on the other hand, it is the search for necessary effective tools for self-improvement and professional self-development and mastering the ability of self-development.

Professional and personal development is accompanied by a constant search for spiritual and professional senses, the achievement of goals and setting the new ones, that is requires self-determination. The essence of a teacher's professional self-determination is the search for and finding one's personal sense in the chosen pedagogical activity or profession; the main purpose of it is the formation of internal readiness to plan independently and consciously, adjust and realize the perspectives of professional and personal growth, the realization of which is accompanied by a person's self-improvement. The meaning of professional selfdetermination is in a person's ability to create oneself, one's individual history, to constantly rethink one's own essence from the standpoint of professional norms. A person's self-determination does not onle involve "selfrealization", but also the expansion of one's original abilities - "self-transcendence" (according to V. Frankl): the full value of a person's life is determined through one's transcendence, that is the ability to "go beyond oneself" and what is the most important - in a person's ability to find new senses in a particular case and in life. It is the sense which determines the essence of self-determination, self-realization and self-transcendence.

We can assume that only by self-determination in the constantly changing conditions of professional and pedagogical activity, a teacher is able to carry it out to the full extent. Professional self-determination is a kind of mechanism for discovering and realizing one's "self" as a professional, the basis for a future teacher's formation, his professional growth. The formed ability for professional and personal self-determination will ensure a teacher's choice of his course of personal and pedagogical life, professional goals and values, that is the formation of a self-developing, self-adapting personality.

There is an inseparable link between a future teacher's professional self-determination and professional selfrealization as a type of creative activity focused on intensification and increase of efficiency of "self"-processes (self-improvement, self-expression, self-realization, etc.). Professional self-realization is a process of the most complete identification of a teacher's individual and professional abilities which is manifested in the assertion of professional image, determining the individual style of professional activity, revealing his creative potential, determining and achieving professional prospects. Thus, the implementation of a teacher's professional selfrealization is an important condition for his professional culture formation.

The emergence of new socio-cultural and professional conditions: the change in educational paradigms, updating the content of academic disciplines, the emergence of new subjects, programmes, new educational technologies require modern teachers to dynamically change personal and actival structures and functional frameworks in which it is necessary to self-determine, self-realize and self-develop. A teacher has to be able to identify the sense of pedagogical activity, which has a dual nature: on the one hand, it is understood as the essence of educational and pedagogical phenomena and serves as a consequence of scientific and pedagogical knowledge, on the other hand, is the result of self-creating activity of a teacher, who determines his professional recognition. A teacher's multi-vector of professional self-determination and self-improvement becomes an important contition, an indicator of his professional culture formation.

Thus, determining a problem field allows us to identify the tasks that should be concentrated around future teachers' culturological and ideological preparation. In this way, the general purpose of culturological preparation should be introducing a student into the sphere of the global and national cultures, practical "interiorizatrion" and "assimilation" of cultural experience, the formation of idea about a human being as a creation and creator of culture, the understanding the importance of pedagogical activities in cultural processes, determining the personal sense of available pedagogical traditions, understanding the values of humanitarian and culture-centric paradigms, which bring "human dimension" to all the spheres of public life. Culturological preparation involves the formation of the axiological orientation of a future teacher's professional thinking, which requires a transition from normative-descriptive to creative-analytical type; the formation of a personal 
culture of a specialist in pedagogical creativity as a means of his self-realization, self-actualization and professional self-creation.

The worldview preparation is aimed at the formation and development of a future teacher's worldview, world perception, world outlook, which has reflection in his system of values - ideals, views, beliefs, goals, and assessments. Serving the formation of the scientific picture of the world, a worldview preparation gives an idea about educational-pedagogical, general human and socio-cultural values, the integration of which into the pedagogical and educational processes determines the content and vector of educational strategies. The central link of worldview preparation should be the formation of a future teacher's worldview positions which determine his attitude to: 1) the humanistic ideal and values, which are subject to the process of induction of new ideas and the creation of various pedagogical processes; 2) axiological approach as a methodological basis of the created cultural and educational space; 3) real and predictable "self-image" as a teacher, educator, facilitator, manager, personal abilities for creative and professional self-determination, and self-creation. The worldview preparation will ensure philosophical, didactic, moral and ethical and other trends of reflective work of a future teacher's conscience [12].

Thus, new opportunities for a future specialist's professional and personal development are opened as he enters and masters more complex and diverse types and structures of activities modelled in the process of professional's preparation, and vice versa, preparation for multifunctional, multi-vector professional and pedagogical activities requires the formation of professionally important qualities, professional self-awareness and thinking, the search for their individual concept in solving pedagogical problems, the formation of their own pedagogical philosophy, which is presented in the "self-conception" and determines the individual style of pedagogical activity.

\section{CONCLUSION}

Basing on the culturological approach, which allows us to consider culture as an individual's universal characteristic, "sets" the socio-humanistic programme and determines the direction of pedagogical activities, their value orientations and results, we offer to consider a future teacher's professional culture as a personal phenomenon, which is manifested in a continuous process of professional and personal development and selfdevelopment, self-actualization, the ability to carry out purposeful actions, find new meanings of professional life, professional "self", professional functions, find ways to realize their "essential forces" and professional and creative self-realization.

\section{REFERENCES}

1. Andruschenko V.P. (2008). Rozdumi pro osvItu: Statti, narisi, interv'yu [Reflections about education: the Articles, essays, interviews]. K.: Znannya UkraYini, 2008. 819 p.

2. Андрущенко В.П.Роздуми про освіту: Статті, нариси, інтерв'ю. К.: Знання України, 2008. 819 c.

3. Ball G.O. (2003). KategorIya «kultura osobistostI» v analIzi gumanIzatsIyi zagalnoyi ta profesIynoyi osviti [A category is a "culture of personality" in the analysis of humanizing of universal and professional education] //Pedagogika i psihologiya profesiynoyi osviti: rezultati doslidzhen i perspektivi: zb. naukovih prats / Za redaktsieyu I.A. Zyazyuna ta N.G. NIchkalo Kiyiv, 2003. P. 51-59.

4. Балл Г.О. Категорія «культура особистості» в аналізі гуманізації загальної та професійної освіти //Педагогіка і психологія професійної освіти: результати досліджень і перспективи: зб. наукових праць / За редакцією .А. Зязюна та 59.

5. Bondarevskaya E.V. (2010). Duhovno-nravstvennaya kultura - osnova stanovleniya rossiyskoy identichnosti molodezhi [Spiritual and moral cuiture - the basis of the formation of the Russian youth identity of young people] / / Chelovek v mire kulturyi: duhovno-nravstvennoe vospitanie i razvitie. Rostov n/D: IPO PI YuFU, 2010. P. 3-9.

6. Бондаревская Е.В. Духовно-нравственная культура - основа становления российской идентичности молодежи / Е. В. Бондаревская // Человек в мире культуры: духовнонравственное воспитание и развитие. Ростов н/Д: ИПО ПИ ЮФУ, 2010. С. 3-9.

7. Gershunskiy B.S. (1998). Filosofiya obrazovaniya dlya XXI veka / V poiskah praktikoorientirovannyih obrazovatelnyih kontseptsiy [Philosophy of education for a XXI century]. M.: Izdatelstvo «Sovershenstvo», 1998. 608 p.

8. Гершунский Б.С. Философия образования для XXI века / В поисках практикоориентированных образовательных концепций / Б.С. Гершунский. М.: Издательство «Совершенство», 1998. 608 с. 
9. Zyazyun I.A. (2000). PedagogIka dobra: ideali i realiyi: Naukovo-metodichniy posibnik [Pedagogics is kind: ideals and realities : Scientifically-methodical textbook]. K.: MAUP, 2000. 312 p.

10. Зязюн І.А. Педагогіка добра: ідеали і реалії: Науково-методичний посібник / Іван Андрійович Зязюн. К.: МАУП, 2000. 312 с.

11. Mitina L.M. (2014). Psihologiya lichnostno-professionalnogo razvitiya sub'ektov obrazovaniya [Psychology of personality-professional development of subjects of education]. M.; SPb.: NestorIstoriya, 2014. $320 \mathrm{p}$.

12. Митина Л.М. Психология личностно-профессионального развития субъектов образования / Л. М. Митина. М.; СПб.: Нестор-История, 2014. 320 с.

13. Kulturologiya: yavleniya i protsessyi: ucheb. posobie / A. I. Arnoldov [Culturology: the phenomena and processes: textbook]. Moskva: Moskovskiy un-t kulturyi i iskusstv, 2007. $407 \mathrm{p}$.

14. Культурология: явления и процессы: [учеб. пособие] / А. И. Арнольдов ; Московский ун-т культуры и искусств. Москва: МГУКИ, 2007. 407 с.

15. PedagogIchna KonstitutsIya Evropi [Pedagogical Constitution of Europe]. Rezhim dostupu: file:// /C:/Users/A/Downloads/74119-155265-1-PB (1).pdf

16. Педагогічна Конституція Європи. Режим доступу: file:///C:/Users/A/Downloads/74119155265-1-PB\%20(1).pdf

17. Pryazhnikov N. S. (2008). Professionalnoe samoopredelenie: teoriya i praktika: ucheb. posobie dlya stud. vyissh. ucheb. zavedeniy [Professional self-determination: theory and practice: textbook] M.: Izdatelskiy tsentr «Akademiya», 2008. 320 p.

18. Пряжников Н.С. Профессиональное самоопределение: теория и практика: учеб. пособие для студ. высш. учеб. заведений / Н.С. Пряжников. М.: Издательский центр «Академия», 2008. 320 c.

19. Slastyonin V.A. i dr. (2013). Pedagogika: uchebnoe posobie dlya studentov vyisshih pedagogicheskih uchebnyih zavedeniy [Pedagogics: textbook]. M.: Izdatelskiy tsentr "Akademiya", 2013. 576 p.

20. Сластёнин В.А. и др. Педагогика: учебное пособие для студентов высших педагогических учебных заведений / В.А. Сластенин, И.Ф. Исаев, Е.Н. Шиянов; Под ред. В.А. Сластенина. М.: Издательский центр "Академия", 2013. 576 с.

21. Filosofiya kulturyi. Stanovlenie i razvitie / Pod red. M. S. Kagana, Yu. V. Petrova, V. V. Prozerskogo [Philosophy of culture. Becoming and development]. SPb: Izdatelstvo «Lan», 2008. $448 \mathrm{p}$.

22. Философия культуры. Становление и развитие / Под ред. М. С. Кагана, Ю. В. Петрова, В. В. Прозерского. СПб: Издательство «Лань», 2008. 448 с.

23. Tusheva V.V. (2013). Zagalna harakteristika profesiynoyi kulturi maybutnogo vchitelya [General description of professional culture of future teacher // Theoretical and methodical principles of forming of scientifically-research culture of future teacher in the process of professional preparation: monograph]. UMO NAPN Ukrayini. Harkiv: Vidavnitstvo «Fedorko», 2013. P. 116126.

24. Тушева В.В. Загальна характеристика професійної культури майбутнього вчителя // Теоретико-методичні засади формування науково-дослідницької культури майбутнього вчителя в процесі професійної підготовки: монографія / В. В. Тушева; УМО НАПН України. Харків: Видавництво «Федорко», 2013. С. 116-126. 